\title{
Fetus papyraceus: a rare case report
}

\author{
Nalam Neelima, Ushadevi Gopalan*
}

\begin{abstract}
Department of Obstetrics and Gynaecology, Shri Sathya Sai Medical College and Research Institute, Ammapettai, Tamil
\end{abstract} Nadu, India

Received: 28 January 2021

Accepted: 04 March 2021

\author{
*Correspondence: \\ Dr. Ushadevi Gopalan, \\ E-mail: ushag7@hotmail.com
}

Copyright: (c) the author(s), publisher and licensee Medip Academy. This is an open-access article distributed under the terms of the Creative Commons Attribution Non-Commercial License, which permits unrestricted non-commercial use. distribution. and reproduction in anv medium. provided the original work is properlv cited.

\begin{abstract}
Fetus papyraceus occurs in multiple pregnancy, more common in monochorionic twin as compared to dichorionic twin. We report a case of 30-year-old gravida two para one living one, previous caesarean section, booked and immunized at private hospital was admitted with labour pains and underwent emergency caesarean section and on examination of placenta found an incidental finding of fetus papyraceus.
\end{abstract}

Keywords: Multiple gestation, Fetus papyraceus, Intrauterine death

\section{INTRODUCTION}

Intra uterine death of one twin and retention of it inside the uterus whose remains are mummified, compressed and are like parchment (dry and paper like) is called fetus papyraceus or fetus compressus. ${ }^{1,2}$ It is a tiny, dry, papery and macerated completely formed fetus. When the co-twin dies at early gestational age the placental tissue and amniotic fluid are absorbed from the dead fetus and it is compressed between uterine wall and membranes of the living twin. ${ }^{3}$ It is sometimes incidentally found on examination of the placenta and membranes of the normal twin after delivery. ${ }^{4}$

Fetus papyraceus occurs in multiple pregnancy. It can occur in monozygotic or dizygotic twins but most common in monozygotic twins. ${ }^{5}$ In recent days incidence of multiple pregnancy is on the rise due to increased incidence of infertility and advances in assisted reproductive techniques. ${ }^{4}$ Incidence of fetus papyraceous ranges from 1:184-1:200 of twin pregnancies and 1:12000 live births. ${ }^{6}$

When the death of co-twin occurs at early gestational period or in 1st trimester, usually the pregnancy conti-nues with few adverse effects on the living twin and the mother. ${ }^{5}$ But if death occurs in 2nd or 3rd trimester there is increased risk for the living twin and more chances of mother being affected with disseminated intravascular coagulation. ${ }^{4,5}$

\section{CASE REPORT}

A 30-year-old gravida two para one living one, previous lower segment caesarean section done 2 years back with gestational age corresponding to 38 weeks 2 days presented to the emergency room with chief complaints of lower abdominal pain on and off since morning. We were able to perceive fetal movements well. No complaints of leaking or bleeding per vaginum. Booked and immunized at a private hospital. Blood investigations and ultrasound found to be normal. Vitals were stable. On examination per abdomen uterus corresponding to term, cephalic presentation, acting, fetal heart rate was good 146 beats/min. Per vaginal examination cervix soft, mid position, cervical os 2 centimeters dilated, membranes present, average pelvis.

In view of the previous caesarean section in labour, the patient was taken up for an emergency caesarean section. She delivered a live term baby with a birth weight of 2.7 kilograms, the baby cried immediately after birth. On 
examination of the placenta and membranes there was an incidental finding of hard, paper like flattened structure which was a shrunken dead fetus - fetus papyraceus. Intra partum and postpartum period uneventful.

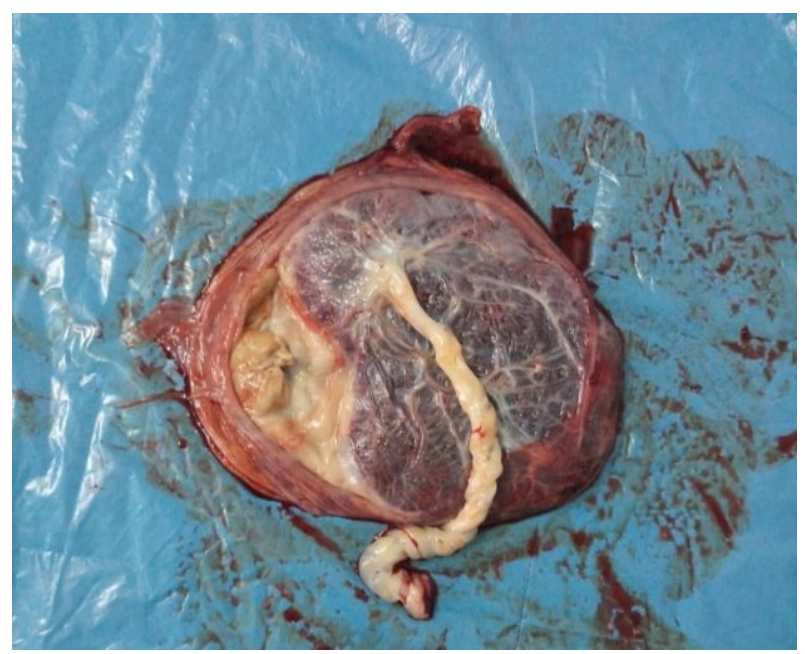

Figure 1: Fetus papyraceus.

\section{DISCUSSION}

Intrauterine death of one of the twins may be due to twinto-twin transfusion syndrome, placental insufficiency, congenital anomalies, velamentous cord insertion, cord stricture. ${ }^{7,8}$ The prognosis of the surviving fetus in a case of fetal demise of co twin depends on factors such as gestational period at the time of death, period between fetal demise and delivery of the surviving fetus, number of fetuses, chorionicity, and cause of death. The prognosis of the surviving twin is better in the dichorionic twin as compared to monochorionic twin. Neurological damage is more common in the surviving monochorionic twin. ${ }^{1,9}$

Ultrasonography can confirm the diagnosis but may not be possible in all cases due to its position and technical difficulties. ${ }^{5}$ If fetus papyraceus was diagnosed during antenatal period, the living twin should be evaluated by serial ultrasonography, Doppler study and biophysical profile. Mother should be followed up by doing serial coagulation profile and to look for development of Disseminated intravascular coagulation. ${ }^{4}$

\section{CONCLUSION}

Even though fetus papyraceus is a rare condition, with the availability of advanced techniques like ultrasound early diagnosis of fetus papyraceous can be made in most of the cases and we can prevent severe complications associated with it. Placenta and membranes should be inspected thoroughly to diagnose any placental abnormality or fetus papyraceus which may be an incidental finding as in our case.

Funding: No funding sources Conflict of interest: None declared

Ethical approval: Not required

\section{REFERENCES}

1. Dahiya P, Bains R. Conservative management of fetus papyraceus: a report of two cases. Oman Med J. 2014;29(2):132-4.

2. Lakshmi S, Rajkumar K. A rare case of fetus papyraceous presenting in monozygotic biamniotic twins. Int J Reprod Contracept Obstet Gynaecol. 2020;9(1):448-9.

3. Malathi J, Brindhini MU, Vanaja P. Fetus papyraceus: a rare case report. Int $\mathrm{J}$ Contemp Med Res. 2017;4(10):2064-5.

4. Usharani N, Joshi SD, Veena D. Fetus papyraceus: a rare case report and review of literature. Int J Sci Stud. 2015;3(4):184-7.

5. Masamatti SS, Ramteerthakar NA, Pandav AB, Gosavi AV. Fetus papyraceus: a rare case report. Ann Path Lab Med. 2015;2(1):28-31.

6. Daw E. Fetus papyraceus - 11 cases. Postgraduate Medical Journal. 1983;59:598-600.

7. Kaushal S, Dogra P, Malhotra K, Tanupriya, Sharma S, Kumar A. Fetus papyraceous- a rare complication of twin pregnancy - a case report. Ann Int Med Den Res. 2017;3(5):9-10.

8. Sindan N, Bhandari A, Rai S, Gurung D. Fetus papyraceus: a rare case report. J Patan Aca Hea Sci. 2020;7(1):113-6.

9. Chaudhari P, Gupta V, Sharma A, Tandon A, Saxena $\mathrm{N}$, Nimonkar S, et al. Obstetric outcome in twin pregnancies complicated with single intrauterine fetal demise. Int J Reprod Contracept Obstet Gynaecol. 2020;9(7):2998-3003.

Cite this article as: Neelima N, Gopalan U. Fetus papyraceus: a rare case report. Int J Reprod Contracept Obstet Gynecol 2021;10:1727-8. 